\title{
PENGARUH MODEL PEMBELAJARAN DISCOVERY LEARNING DAN PROBLEM BASED LEARNING (PBL) PADA MATERI POKOK KELARUTAN DAN HASIL KALI KELARUTAN (Ksp) DITINJAU DARI KEMAMPUAN BERPIKIR LOGIS TERHADAP PRESTASI BELAJAR SISWA KELAS XI MIPA SMA NEGERI 1 SRAGEN
}

\author{
Akhmad Zaenuddin Jazuli, Sulistyo Saputro*, dan Bakti Mulyani \\ Program Studi Pendidikan Kimia, FKIP, Universitas Sebelas Maret, Surakarta, Indonesia \\ *keperluan korespondensi, tel/fax : 081329196891, email: sulistyo_s@staff.uns.ac.id
}

\begin{abstract}
ABSTRAK
Tujuan dari penelitian ini untuk mengetahui, (1) Pengaruh model pembelajaran Discovery Learning dan model pembelajaran Problem Based Learning (PBL) pada materi pokok Kelarutan dan Hasil Kali Kelarutan (Ksp) terhadap prestasi belajar siswa. (2) Pengaruh kemampuan berpikir logis tinggi dan kemampuan berpikir logis rendah siswa terhadap prestasi belajar. (3) Interaksi antara model pembelajaran Discovery Learning dan Problem Based Learning (PBL) dengan kemampuan berpikir logis yang dimiliki siswa. Penelitian ini merupakan penelitian eksperimen dengan menggunakan rancangan penelitian desain faktorial $2 \times 2$. Populasi penelitian ini merupakan siswa kelas XI MIPA semester genap SMA Negeri 1 Sragen tahun pelajaran 2017/2018. Sampel pada penelitian ini adalah siswa kelas XI MIPA 1 dan XI MIPA 2 dengan teknik pengambilan sampel menggunakan cluster random sampling. Pada kelas eksperimen I diterapkan model pembelajaran Discovery Learning dan kelas eksperimen II menggunakan model pembelajaran Problem Based Learning (PBL). Teknik pengumpulan data adalah melalui teknik tes yang digunakan untuk mengambil data prestasi belajar pada aspek pengetahuan dan kemampuan berpikir logis dan teknik non tes digunakan untuk mengambil data pada aspek sikap dan aspek keterampilan. Pengujian hipotesis dalam penelitian ini menggunakan Analisis Variansi (ANAVA) dua jalan dengan sel tak sama yang digunakan untuk prestasi belajar aspek pengetahuan, dan uji statistik non parametrik Kruskal Wallis digunakan pada aspek sikap dan ketrampilan. Berdasarkan hasil penelitian diperoleh kesimpulan, (1) Penerapan model pembelajaran Discovery Learning dengan model pembelajaran Problem Based Learning (PBL) tidak menunjukkan perbedaan prestasi belajar siswa pada materi pokok Kelarutan dan Hasil Kali Kelarutan (Ksp) baik dari aspek pengetahuan, aspek sikap, maupun, aspek ketrampilan. (2) Kemampuan berpikir logis siswa berpengaruh pada prestasi belajar aspek pengetahuan dan tidak berpengaruh pada prestasi belajar aspek sikap dan aspek ketrampilan pada materi pokok Kelarutan dan Hasil Kali Kelarutan (Ksp). (3) Pada prestasi belajar siswa pada aspek sikap menunjukkan adanya interaksi antara model pembelajaran Discovery Learning dan model pembelajaran Problem Based Learning (PBL) dengan kemampuan berpikir logis siswa. Akan tetapi pada aspek pengetahuan dan aspek ketrampilan tidak menunjukkan adanya interaksi antara model pembelajaran Discovery Learning dan model pembelajaran Problem Based Learning (PBL) dengan kemampuan berpikir logis siswa.
\end{abstract}

Kata Kunci : Discovery Learning, PBL, kemampuan berpikir logis, Kelarutan dan Hasil Kali Kelarutan (Ksp) (Ksp)

\section{PENDAHULUAN}

Definisi pendidikan berdasarkan UU SISDIKNAS No. 20 Tahun 2003 merupakan kegiatan yang sengaja dan terencana didesain untuk mengembang- kan potensi individu, sehingga menjadi sangat penting untuk perkembangan generasi suatu bangsa. Dimana dalam pelaksanaannya, diperlukan dukungan dari berbagai pihak, mulai dari pemerintah, lembaga pendidiakan, dan 
masyarakat. Pemerintah melalui Kementerian Pendidikan telah berusaha memperbaiki kualitas pendidikan di Indonesia salah satunya penyesuaian kurikulum pendidikan dengan perkembangan zaman. Kurikulum diatur dalam Undang-undang Pendidikan Nasional, yang didefinisikan sebagai seperangkat rencana dan pengaturan mengenai tujuan, isi, dan bahan pelajaran serta cara yang digunakan sebagai pedoman penyelenggaraan kegiatan pembelajaran untuk mencapai tujuan pendidikan. Adanya penyesuaian kurikulum ini diharapkan mampu meningkatkan kualitas pendidikan di Indonesia. Akan tetapi pada kenyataannya, perubahan kurikulum belum sepenuhnya mampu diimbangi dengan kesiapan dari pihakpihak yang terkait.

Prestasi belajar siswa SMA di Kabupaten Sragen pada hasil ujian nasional tahun 2015-2017 diketahui masih relatif rendah dengan rata-rata nilai kurang dari 75 . Bahkan di beberapa sekolah rata-rata nilai tidak mencapai 50. Kemudian berdasarkan analisis data ujian nasional dari kemendikbud pada tahun tersebut diketahui mata pelajaran kimia menjadi salah satu yang memiliki rata-rata relatif rendah dibandingkan mata pelajaran lain, dengan kisaran ratarata nilai 37,85 sampai 70,90 . Berdasarkan data tersebut dapat disimpulkan bahwa mata pelajaran kimia masih menjadi salah satu mata pelajaran yang dianggap sulit oleh sebagian siswa SMA, khususnya di kabupaten Sragen [1].

SMA Negeri 1 Sragen merupakan salah satu sekolah favorit di kabupaten Sragen, Jawa Tengah. Sebagai sekolah unggulan, SMA Negeri 1 Sragen memiliki sistem pendidikan dan fasilitas yang cukup memadai, tetapi tiga tahun terakhir diketahui terjadi penurunan prestasi belajar siswa, salah satunya pada mata pelajaran Kimia. Berdasarkan analisis hasil Ujian Nasional, diketahui beberapa kompetensi dasar mengalami penurunan presatasi belajar. Salah satu Kompetensi Dasar yang mengalami penurunan adalah pada KD 3.14 yakni materi pokok larutan dan sifat-sifatnya.
Tabel 1. Analisis Hasil Ujian Nasional SMA N 1 Sragen pada Mata Pelajaran Kimia

\begin{tabular}{ccc}
\hline No & Tahun & Rata-rata Nilai UN \\
\hline 1 & 2013 & 77,21 \\
2 & 2014 & 56.54 \\
3 & 2015 & 63.17 \\
\hline
\end{tabular}

Berdasarkan hasil informasi dan observasi, siswa-siswi SMA Negeri 1 Sragen cenderung lebih menyukai pembelajaran secara konvensional. Penggunaan model pembelajaran yang disarankan sesuai kurikulum 2013 belum bisa diterapkan secara efektif.

Penggunaan model pembelajaran pada proses belajar dan mengajar tidak boleh sembarangan. Ketepatan penggunaan metode pembelajaran yang diterapkan guru dapat meningkatkan pemahaman siswa terhadap mata pelajaran yang akan disampaikan. Model pembelajaran yang cocok untuk materi Kelarutan dan Hasil Kali Kelarutan (Ksp) sesuai dengan karakteristik materinya, antara lain model pembelajaran Discovery Learning dan Problem Based Learning (PBL).

Discovery Learning sebagai salah satu model pembelajaran yang beraliran psikologi kognitif, model pembelajaran ini bertujuan untuk meningkatkan kemampuan berpikir siswa. PBL yang juga beraliran psikologi kognitif sebagai pendukung teoritisnya, dengan fokus utama pada apa yang dipikirkan siswa (kognisi siswa), bukan perilaku apa yang sedang dilakukan siswa [2]. Pendekatan pada model pembelajaran PBL dapat melatih siswa untuk mampu memecahkan suatu masalah. Akan tetapi model pembelajaran ini juga memiliki kekurangan, yakni pada pembelajaran PBL tidak dapat mencapai tujuannya apabila siswa yang terlibat dalam pembelajaran tidak aktif, selain itu model pembelajaran PBL juga tidak bisa diterapkan pada semua materi pembelajaran [3]. Sedangkan model pembelajaran Discovery Learning dianggap dapat mengembangkan cara belajar siswa aktif melalui kegiatan menemukan dan menyelidiki suatu masalah, sehingga 
hasil yang diperoleh bertahan lama di dalam ingatan mereka (long term memory) [4]. Disisi lain, model pembelajaran Discovery Learning juga memiliki kelemahan yaitu pada model pembelajaran ini membutuhkan waktu yang lebih lama daripada model pembelajaran yang lain. Selain itu, asumsi bahwa setiap anak mampu proaktif dengan kemampuan kognitif mereka tidak sepenuhnya tepat [5].

Disisi lain, mata pelajaran Kimia merupakan salah satu mata pelajaran sains yang membutuhkan pemahaman mendalam. Kemampuan berpikir logis yang berkembang akan sangat membantu siswa dalam menemukan konsepkonsep suatu materi. Berpikir logis merupakan suatu cara berpikir runtut dan masuk akal serta atas dasar fakta-fakta yang objektif [6]. Salah satu materi pokok kimia di kelas XI semester genap adalah Kelarutan dan Hasil Kali Kelarutan (Ksp). Di dalam materi ini, memuat penjelasan tentang molekul, garan-garam, ion-ion, dll. Konsep-konsep tersebut pada umumnya bersifat mikroskopis. Oleh karenanya kemampuan berpikir logis siswa menjadi penting untuk membantu siswa dalam memahami konsep-konsep kelarutan.

Berdasarkan uraian tersebut, diketahui salah satu faktor yang mempengaruhi dan menyebabkan penurunan prestasi belajar siswa SMA N 1 Sragen adalah penggunaan model pembelajaran yang kurang tepat. Untuk mengetahui pengaruh model pembelajaran terhadap prestasi belajar adalah dengan melakukan serangkaian penelitian eksperimental yang membandingkan dua model pembelajaran.

Pada materi pokok Kelarutan dan Hasil Kali Kelarutan (Ksp), memiliki submateri yang cukup banyak, sehingga penggunaan model pembelajaran yang relatif membutuhkan waktu singkal akan lebih membantu. Di sisi lain, ingatan jangka panjang (long term memory) siswa juga penting, mengingat bahwa dalam materi tersebut juga terdapat rumus-rumus dan konsep-konsep yang membutuhkan kemampuan mengingat. Kedua model pembelajaran tersebut memiliki karakteristik, kelebihan, dan kekurangan masing-masing. Dari kelebihan masing-masing, baik model pembelajaran Discovery Learning dan model pembelajaran Problem Based Learning (PBL) dapat mendukung pembelajaran kimia pada materi Kelarutan dan Hasil Kali Kelarutan (Ksp).

\section{METODE PENELITIAN}

Penelitian ini merupakan penelitian eksperimen yang melibatkan dua kelas, yaitu kelas eksperimen I dan kelas eksperimen II. Kedua kelompok eksperimen ini diuji keseimbangannnya terlebih dulu (uji matching). Rancangan penelitian yang digunakan adalah desain faktorial $2 \times 2$. Rancangan penelitian tersebut dapat dilihat pada Tabel 2.

Tabel 2. Rancangan Penelitian Desain Faktorial $2 \times 2$

\begin{tabular}{cccc}
\hline & Model & \multicolumn{2}{c}{ Kemampuan } \\
Eks & $\begin{array}{c}\text { Pembel } \\
\text { ajaran }\end{array}$ & $\begin{array}{c}\text { Tinggi } \\
\left(\mathrm{B}_{1}\right)\end{array}$ & $\begin{array}{c}\text { Rendah } \\
\left(\mathrm{B}_{2}\right)\end{array}$ \\
\hline I & $D L\left(\mathrm{~A}_{1}\right)$ & $\mathrm{A}_{1} \mathrm{~B}_{1}$ & $\mathrm{~A}_{1} \mathrm{~B}_{2}$ \\
II & $P B L\left(\mathrm{~A}_{2}\right)$ & $\mathrm{A}_{2} \mathrm{~B}_{1}$ & $\mathrm{~A}_{2} \mathrm{~B}_{2}$ \\
\hline
\end{tabular}

Sampel yang digunakan pada penelitian ini merupakan dua kelas yang diambil dari keseluruhan kelas XI MIPA melalui teknik pengambilan sampel cluster random sampling. Kelas eksperimen I (XI MIPA 1) dengan model pembelajaran Discovery Learning dan kelas eksperimen II (XI MIPA 2) dengan model pembelajaran Problem Based Learning (PBL)

Aspek penilaian meliputi aspek pengetahuan, sikap, dan ketrampilan. Sumber data dalam penelitian ini berupa metode tes untuk mengukur kemampuan berpikir logis siswa (TOLT) dan prestasi pada aspek pengetahuan, sedangkan metode non-tes untuk aspek sikap (angket \& observasi) dan aspek keterampilan (observasi). Data yang diperoleh berasal dari prestasi belajar siswa pada materi pokok Kelarutan dan Hasil Kali Kelarutan (Ksp). Dengan teknik analisis data menggunakan uji analisis variansi (ANAVA) dua jalan sel tak sama untuk data yang terdistrubusi normal dan uji Kruskal Wallis untuk data yang tidak 
terdistrubusi normal. Uji prasyarat analisis dan uji hipotesis dalam penelitian ini dilakukan dengan bantuan Software SPSS v. 23.

\section{HASIL DAN PEMBAHASAN}

Sebelum dilakukan analisis nonparametrik, data hasil penelitian terlebih dahulu dilakukan uji prasyarat analisis. Dimana pada uji hipotesis ANAVA dua jalan sel tak sama harus memenuhi uji normalitas dan uji homogenitas data. Sedangkan data yang tidak memenuhi uji normalitas dan uji homogenitas atau salah satunya, maka pengujian hipotesis dilakukan dengan uji Kruskal Wallis. Uji normalitas (Kolmogorov-Smirnov) dilakukan untuk mengetahui apakah sampel dari hasil penelitian berasal dari populasi yang normal atau tidak. Berdasarkan analisis uji normalitas diketahui semua kelompok siswa pada aspek pengetahuan memiliki data yang normal, kemudian pada aspek keterampilan sebagian besar data normal akan tetapi ada beberapa data yang tidak normal, sedangkan pada aspek sikap justru semua data tidak normal. Selain itu, data hasil penelitian perlu dilakukan uji homogenitas untuk mengetahui apakah sampel hasil penelitian berasal dari populasi yang homogen atau tidak. Berdasarkan hasil uji homogenitas ditinjau dari model pembelajaran diketahui pada aspek pengetahuan dan aspek sikap data homogen sedangkan pada aspek ketrampilan data tidak homogen, kemudian uji homogenitas ditinjau dari kemampuan berpikir logis, diketahui pada aspek pengetahuan dan aspek ketrampilan menunjukan data homogen sedangkan pada aspek sikap data tidak homogen. Kemudian uji homogenitas antar sel menunjukan pada aspek pengetahuan dan aspek ketrampilan menunjukan data homogen sedangkan pada aspek sikap data tidak homogen.

Rata-rata nilai prestasi belajar siswa pada aspek pengetahuan dari kedua kelas eksperimen dan kedua kategori kemampuan berpikir logis disajikan pada Tabel 3. Sedangkan hasil uji Anava nilai prestasi pada aspek pengetahuan disajikan pada Tabel 4 .

Tabel 3. Rata-rata dan Jumlah Rata-rata Nilai Prestasi Pengetahuan.

\begin{tabular}{lccc}
\hline \multirow{2}{*}{ Model } & \multicolumn{2}{c}{$\begin{array}{c}\text { Kemampuan } \\
\text { Berpikir Logis }\end{array}$} & \multirow{2}{*}{ Total } \\
\cline { 2 - 3 } & $\begin{array}{c}\text { Tinggi } \\
\left(\mathrm{B}_{1}\right)\end{array}$ & $\begin{array}{c}\text { Rendah } \\
\left(\mathrm{B}_{2}\right)\end{array}$ & \\
\hline$D L\left(\mathrm{~A}_{1}\right)$ & 64,17 & 54,75 & 118,92 \\
$\operatorname{PBL}\left(\mathrm{A}_{2}\right)$ & 64,37 & 53,47 & 117,84 \\
\hline Total & 128,54 & 108,22 & 236,76 \\
\hline
\end{tabular}

Tabel 4. Rangkuman Analisis Variansi Dua Jalan Sel Tak Sama pada Nilai Prestasi Pengetahuan

\begin{tabular}{|c|c|c|c|}
\hline Sumber & $\alpha$ & Sig. & Keputusan \\
\hline $\begin{array}{l}\text { Model } \\
\text { Pembelajaran }(\mathrm{A})\end{array}$ & 0,05 & 0,953 & $\begin{array}{c}\mathrm{Ho} \\
\text { diterima }\end{array}$ \\
\hline $\begin{array}{l}\text { Kemampuan } \\
\text { Berpikir Logis (B) }\end{array}$ & 0,05 & 0,017 & Ho ditolak \\
\hline Interaksi (AB) & 0,05 & 0,996 & $\begin{array}{c}\text { Ho } \\
\text { diterima }\end{array}$ \\
\hline
\end{tabular}

Data prestasi belajar siswa pada aspek sikap data tidak berasal dari distribusi normal dan data tidak homogen, maka dari itu untuk pengujian hipotesis menggunakan Uji Statistik NonParametrik Kruskal Wallis. Berikut ini merupakan data rata-rata nilai prestasi belajar aspek sikap dari kedua kelas eksperimen dan kedua kategori kemampuan berpikir logis disajikan pada Tabel 5. dan hasil Uji Statistik NonParametrik Kruskal Wallis disajikan pada Tabel 6.

Tabel 5. Rata-rata dan Jumlah Rata-rata Nilai Prestasi Sikap.

\begin{tabular}{lccc}
\hline \multirow{2}{*}{ Model } & \multicolumn{2}{c}{$\begin{array}{c}\text { Kemampuan } \\
\text { Berpikir Logis }\end{array}$} & \multirow{2}{*}{ Total } \\
\cline { 2 - 3 } & $\begin{array}{c}\text { Tinggi } \\
\left(\mathrm{B}_{1}\right)\end{array}$ & $\begin{array}{c}\text { Rendah } \\
\left(\mathrm{B}_{2}\right)\end{array}$ & \\
\hline$D L\left(\mathrm{~A}_{1}\right)$ & 3,0 & 3,45 & 6,45 \\
$P B L\left(\mathrm{~A}_{2}\right)$ & 3,31 & 3,37 & 6,68 \\
\hline Total & 6,31 & 6,82 & 13,13 \\
\hline
\end{tabular}


Tabel 6. Rangkuman Uji Kruskal Wallis pada Nilai Prestasi Belajar Siswa Aspek Sikap.

\begin{tabular}{|c|c|c|c|}
\hline Sumber & $\alpha$ & Sig. & Keputusan \\
\hline $\begin{array}{l}\text { Model } \\
\text { Pembelajaran }(A)\end{array}$ & 0,05 & 0,553 & $\begin{array}{c}\text { Ho } \\
\text { diterima }\end{array}$ \\
\hline $\begin{array}{l}\text { Kemampuan } \\
\text { Berpikir Logis (B) }\end{array}$ & 0,05 & 0,065 & $\begin{array}{c}\text { Ho } \\
\text { diterima }\end{array}$ \\
\hline Interaksi (AB) & 0,05 & 0,034 & $\begin{array}{l}\text { Ho } \\
\text { ditolak }\end{array}$ \\
\hline
\end{tabular}

Data prestasi belajar siswa pada aspek ketrampilan dalam penelitian ini, tidak memenuhi prasyarat analisis untuk uji hipotesis dengan ANAVA. Hal ini dikarenakan terdapat beberapa data yang tidak berasal dari distribusi normal maupun tidak homogen, maka dari itu untuk pengujian hipotesis penelitiannya adalah dengan menggunakan Uji Statistik Non-parametrik Kruskal Wallis. Berikut rata-rata nilai prestasi belajaar aspek ketrampilan yang telah terangkum pada Tabel 7. dan hasil Uji Kruskal Wallis disajikan pada Tabel 8.

Tabel 7. Rata-rata dan Jumlah Rata-rata Nilai Prestasi Belajar Aspek Keterampilan.

\begin{tabular}{lccc}
\hline & \multicolumn{3}{c}{ Kemampuan Berpikir } \\
Model & \multicolumn{2}{c}{ Logis } & \multirow{2}{*}{ Total } \\
\cline { 2 - 3 } & $\begin{array}{c}\text { Tinggi } \\
\left(\mathrm{B}_{1}\right)\end{array}$ & $\begin{array}{c}\text { Rendah } \\
\left(\mathrm{B}_{2}\right)\end{array}$ & \\
\hline$\left(\mathrm{A}_{1}\right)$ & 82,52 & 83,95 & 166,47 \\
$\left(\mathrm{~A}_{2}\right)$ & 88,19 & 86,80 & 174,99 \\
\hline Total & 170,71 & 170,75 & 341,46 \\
\hline
\end{tabular}

Tabel 8. Rangkuman Uji Kruskal Wallis pada Prestasi Belajar Siswa Aspek Keterampilan.

\begin{tabular}{|c|c|c|c|}
\hline Sumber & $\alpha$ & Sig. & Keputusan \\
\hline $\begin{array}{l}\text { Model } \\
\text { Pembelajaran (A) }\end{array}$ & 0,05 & 0,210 & \multirow{3}{*}{$\begin{array}{c}\text { Ho } \\
\text { diterima } \\
\text { Ho } \\
\text { diterima } \\
\text { Ho } \\
\text { diterima }\end{array}$} \\
\hline $\begin{array}{l}\text { Kemampuan } \\
\text { Berpikir Logis (B) }\end{array}$ & 0,05 & 0,8 & \\
\hline Interaksi $(A B)$ & 0,05 & 0,642 & \\
\hline
\end{tabular}

\section{Hipotesis pertama}

Pengujian hipotesis pertama adalah untuk mengetahui ada tidaknya pengaruh model pembelajaran terhadap prestasi belajar siswa pada materi Kelarutan dan Hasil Kali Kelarutan (Ksp). Hasil pengujian hipotesis melalui ANAVA dua jalan sel tak sama pada Tabel 4, dan pengujian hipotesis melalui uji Kruskal Wallis pada Tabel 6. Tabel 8, menunjukkan bahwa tidak ada pengaruh antara pembelajaran menggunakan model Discovery Learning dengan pembelajaran menggunakan model Problem Based Learning pada materi pokok Kelarutan dan Hasil Kali Kelarutan (Ksp) terhadap prestasi belajar siswa. Baik pada aspek pengetahuan, sikap, maupun keterampilan ketiganya tidak menunjukkan perbedaan yang signifikan.

Berdasarkan hasil pengujian dengan menggunakan ANAVA dua jalan sel tak sama pada aspek pengetahuan menghasilkan nilai Sig. (p) $=0,952>0,05$ sehingga $\mathrm{H}_{0}$ diterima dan $\mathrm{H}_{1}$ ditolak. Hal ini menunjukkan bahwa tidak ada perbedaan prestasi belajar siswa aspek pengetahuan antara model pembelajaran Discovery Learning dengan model pembelajaran Problem Based Learning. Berdasarkan Tabel 3. diketahui prestasi belajar siswa kedua kelas memiliki rata-rata yang berbeda. Apabila di dasarkan pada nilai rata-rata, maka diketahui model pembelajaran Problem Based Learning relatif lebih baik apabila di terapkan pada materi pokok Kelarutan dan Hasil Kali Kelarutan (Ksp).

Tidak adanya pengaruh model pembelajaran terhadap prestasi belajar aspek pengetahuan dimungkinkan akibat terbatasnya waktu dan ketidaksiapan siswa. Seperti yang telah di jelaskan di awal bahwa pelaksanaan model pembelajaran baik Discovery Learning maupun model pembelajaran Problem Based Learning, keduanya memerlukan waktu yang cukup lama untuk mengatasi suatu masalah sampai siswa menemukan konsep secara mandiri. Akan tetapi pada kenyataannya kurangnya waktu pembelajaran mengakibatkan pelaksanaan model pembelajaran tersebut tidak dapat berjalan sesuai dengan Rencana Pelaksanaan Pembelajaran yang telah di buat. Salah satu yang menjadi kekurangan dari model pembelajaran PBL adalah membutuhkan waktu yang relatif banyak [3]. Sedangkan pada model 
pembelajaran Discovery Learning, membutuhkan waktu yang lebih lama daripada model pembelajaran lain [5].

Selain akibat waktu yang tidak cukup, faktor lain yang juga dimungkinkan menjadi penyebab ketidak sesuaian tersebut yaitu ketidaksiapan siswa-siswi untuk melaksanakan kegiatan pembelajaran dengan model pembelajaran yang diterapkan pada kedua kelas eksperimen. Banyak siswa yang mungkin masih belum paham dengan sintakssintaks yang dijelaskan di awal pembelajaran, akibatnya apa yang dilakukan siswa tidak sesuai dengan sintaks tersebut. Kegagalan pada model pembelajaran Problem Based Learning adalah sifat pasif dari siswanya [2]. Selain itu pada model pembelajaran tersebut tidak akan mencapai tujuannya, apabila siswa tidak aktif [3]. Perilaku siswa tersebut dapat dimaklumi, karena memang mungkin model pembelajaran Discovery Learning dan model pembelajaran Problem Based Learning belum pernah diberlakukan sebelumnya.

Pada aspek sikap, hasil pengujian melalui statistik uji Kruskal Wallis, dihasilkan nilai Sig. $(p)=0,553>0,05$ sehingga $\mathrm{H}_{0}$ diterima dan $\mathrm{H}_{1}$ ditolak. Dengan demikian, dapat disimpulkan bahwa dari kedua model pembelajaran yang diterapkan menunjukkan bahwa tidak ada pengaruh model pembelajaran Discovery Learning pada kelas eksperimen I dan model pembelajaran Problem Based Learning pada kelas eksperimen II.

Prestasi belajar siswa pada aspek sikap tidak dapat disimpulkan hanya dengan satu atau dua pengamatan saja, pada aspek sikap tidak dapat diperoleh secara sekejap namun dapat diterapkan menggunakan pembiasaan (habituating). Pembiasaan dan pengalaman yang dimaksud tentunya melalui proses yang tidak sebentar [7]. Misalnya, apabila siswa yang sudah terbiasa bertindak tidak jujur, akan sulit diubah menjadi jujur dalam dua atau tiga kali pertemuan saja. Selain membutuhkan waktu panjang untuk menentukan suatu sikap (kebiasaan) siswa, faktor internal misalnya kondisi mental dan fisik seseorang juga dapat menunjukkan hasil yang berbeda pada sikap yang ditunjukkan. Sikap adalah proses pembiasaan kesiapan mental yang diperoleh dalam proses hidupnya [8]. Oleh karenanya tidak adanya perbedaan prestasi belajar siswa pada aspek sikap dimungkinkan karena karakteristik dari aspek sikap itu sendiri. Sikap merupakan suatu kebiasaan seseorang yang sudah melekat dalam diri individu, melalui suatu proses yang panjang. Sikap cenderung merupakan faktor internal sedangkan model pembelajaran merupakan suatu faktor eksternal.

Pada aspek sikap, hasil pengujian melalui uji Kruskal Wallis, yang disajikan dalam Tabel 6. diperoleh Sig. $(p)=0,210$ $>0,05$, sehingga $\mathrm{Ho}$ diterima dan $\mathrm{H}_{1}$ ditolak dengan demikian dapat di simpulkan bahwa pada penelitian yang dilakukan berdasarkan statistik uji hipotesisi Kruskal Wallis tidak ada pengaruh model pembelajaran Discovery Learning dan model pembelajaran Problem Based Learning terhadap prestasi belajar siswa pada aspek keterampilan.

Faktor-faktor yang mungkin menjadi penyebab utama tidak adanya pengaruh model pembelajaran terhadap prestasi belajar aspek keterampilan adalah kurang lengkapnya data penelitian serta ketidak aktifan siswa selama mengikuti pembelajaran. Pada penelitian ini, data prestasi belajar siswa pada aspek keterampilan diperoleh dari hasil observasi siswa tanpa praktikum di laboratorium, sehingga keterampilan yang teramati tidak sepenuhnya mewakili keterampilan siswa pada penyelesaian masalah secara ilmiah. Di sisi lain, ketidaktahuan siswa pada sintaks pembelajaran mengakibatkan kurangnya keaktifan dan antusias mereka.

\section{Hipotesis kedua}

Pengujian hipotesis kedua adalah untuk mengetahui ada tidaknya pengaruh kemampuan berpikir logis terhadap prestasi belajar siswa pada materi pokok Kelarutan dan Hasil Kali Kelarutan (Ksp). Berpikir logis merupakan suatu tingkatan pemikiran yang dimulai dari sederhana hingga kompleks dengan menggunakan penalaran untuk memperoleh kesim- 
pulan. Untuk mengukur kemampuan berpikir logis dilakukan dengan suatu test yang dikembangkan oleh Tobin dan Capie (1981) yaitu Test of Logical Thinking (TOLT) dengan lima jenis penalaran yaitu : (1) kontrol variabel (controlling variable), (2) penalaran proporsional (proportional reasoning), (3) penalaran probabilistik (probalistic reasoning), (4) penalaran korelasional (correlational reasoning) dan (5) penalaran kombinatorik (combinatorial thingking). Data yang diperoleh kemudian akan dapat disimpulkan men-jadi dua kategori dengan pembanding nilai ratarata kelompok siswa [9] [10].

Berdasarkan hasil dari uji hipotesis ANAVA dua jalan pada aspek pengetahuan menunjukkan bahwa ada pengaruh antara kemampuan berpikir logis tinggi dan kemampuan berpikir logis rendah terhadap prestasi belajar aspek pengetahuan siswa pada materi pokok Kelarutan dan Hasil Kali Kelarutan (Ksp). Secara umum, berdasarkan hasil penelitian yang terangkum dalam Tabel 3 , menunjukkan bahwa pada siswa-siswi yang memiliki kemampuan berpikir logis tinggi memiliki prestasi belajar yang lebih tinggi daripada siswa-siswi yang memiliki kemampuan berpikir logis rendah.

Kemampuan berpikir logis adalah kemampuan internal siswa yang berpengaruh pada cara siswa dalam mengolah informasi. Proses mengolah informasi tersebut merupakan bagian dari kemampuan kognisi mereka [11]. Oleh karena itu pada penelitian ini, siswa-siswa yang memiliki kemampuan berpikir logis tinggi menunjukkan prestasi belajar yang lebih baik daripada siswasiswa yang memiliki kemampuan berpikir logis rendah. Kemampuan berpikir logis memiliki jenis penalaran yang beraneka ragam dan tidak semua penalaran dibutuhkan ketika seseorang mengolah suatu informasi. Sehingga, tiap-tiap siswa memiliki kecenderungan jenis penalaran tertentu dan khusus. Selain itu untuk menguasai suatu konsep ternyata tidak diperlukan penguasaan yang tinggi pada semua jenis penalaran. Akan tetapi, cukup dengan menguasai secara kuat pada beberapa jenis penalaran untuk dapat menguasai konsep tertentu [10].

Pada aspek sikap, hasil pengujian melalui uji Kruskal Wallis, dihasilkan nilai Sig. $(p)=0,065>0,05$ sehingga $\mathrm{H}_{0}$ diterima dan $\mathrm{H}_{1}$ ditolak. Dengan demikian, dapat disimpulkan tidak ada pengaruh antara siswa yang memiliki kemampuan berpikir logis tinggi dengan siswa yang memiliki kemampuan berpikir logis rendah terhadap prestasi belajar siswa aspek sikap.

Pada penelitian ini, prestasi belajar pada aspek sikap yang diamati dengan observasi dan analisis angket, meliputi sikap spiritual siswa, serta sikap sosial antara lain; jujur, percaya diri, tanggung jawab, dan kerjasama. Apabila dipahami dari pengertian kemampuan berikir logis itu sendiri, maka tidak ada keterkaitannya dengan aspek sikap seseorang. Aspek sikap lebih mencerminkan pada tindakan, tanggapan, dan perasaan seseorang terhadap sesuatu. Selain itu, sikap merupakan bentukan dari pembiasaan seseorang selama masa hidupnya (membutuhkan waktu yang lama), berbeda dengan kemampuan berpikir logis yang merupakan faktor internal seseorang yang dibawa sejak lahir dan mengalami perkembangan selama masa hidupnya.

Pada aspek ketrampilan, diketahui beberapa data tidak memenuhi prasyarat uji ANAVA sehingga pengujian hipotesis menggunakan uji non-parametrik Kruskal Wallis dengan hasil Sig. ( $p)=0,850>$ 0,05 sehingga $\mathrm{H}_{0}$ diterima dan $\mathrm{H}_{1}$ ditolak. Dengan demikian, dapat disimpulkan tidak ada pengaruh antara siswa yang memiliki kemampuan berpikir logis tinggi dengan siswa yang memiliki kemampuan berpikir logis rendah terhadap prestasi belajar siswa aspek ketrampilan.

Pada penilaian aspek keterampilan ini, dilakukan melalui observasi siswa. Oleh karenanya sumber data utama dari aspek ketrampilan ini, berasal dari observasi aktivitas siswa selama pelaksanaan pembelajaran dan analisis hasil pekerjaan siswa. Kurangnya sumber data tersebut dimungkinkan menjadi salah satu penyebab uji hipotesis menunjukan tidak adanya interaksi. Selain itu kemampuan berpikir 
logis atau berlogika merupakan kemampuan internal siswa yang berhubungan dengan cara siswa dalam menggunkan logikanya untuk menyelesaikan masalah berdasarkan informasi yang ada [11]. Sedangkan menurut kurikulum 2013 aspek keterampilan merupakan kemampuan yang dipengaruhi oleh motorik siswa dalam melakukan kerja laboratorium dan keterampilan dalam mencipta, hal tersebut disebabkan karena berpikir logis berperan pada ranah kognitif siswa sedangkan ketrampilan siswa lebih dibutuhkan pada kemempuan motorik siswa [12].

\section{Hipotesis ketiga}

Pengujian hipotesis ketiga adalah untuk mengetahui ada tidaknya interaksi antara model pembelajaran Discovery Learning dan PBL dengan kemampuan berpikir logis terhadap prestasi belajar siswa pada materi pokok Kelarutan dan Hasil Kali Kelarutan (Ksp). Berdasarkan hasil pengujian hipotesis melalui uji ANAVA pada Tabel 4. menunjukkan bahwa tidak ada interaksi antara model pembelajaran Discovery Learning dan PBL dengan kemampuan berpikir logis terhadap prestasi belajar siswa pada materi pokok Kelarutan dan Hasil Kali Kelarutan (Ksp) aspek pengetahuan. Kemudian pada hasil pengujian melalui uji Kruskal Wallis pada Tabel 6. untuk aspek ketrampilan juga menunjukkan tidak adanya interaksi. Sedangkan pada prestasi belajar aspek sikap melalui statistik uji Kruskal Wallis pada Tabel 8. menunjukkan bahwa ada interaksi antara model pembelajaran Discovery Learning dan PBL dengan kemampuan berpikir logis terhadap prestasi belajar siswa pada materi pokok Kelarutan dan Hasil Kali Kelarutan (Ksp).

Tidak adanya interaksi antara model pembelajaran Discovery Learning (kelas eksperimen I) dan model pembelajaran Problem Based Learning (kelas eksperimen II) dengan kemampuan berpikir logis terhadap prestasi belajar aspek pengetahuan siswa. Dengan kata lain, tidak ada perbedaan efek yang signifikan antara siswa yang belajar dengan model pembelajaran Discovery Learning (kelas Eksperimen I) dan Problem Based Learning (eksperimen II) ditinjau dari kemampuan berpikir logis terhadap prestasi pengetahuan siswa.

Kemampuan berpikir logis diketahui dapat mempengaruhi prestasi belajar, akan tetapi tidak mutlak baik buruknya prestasi belajar hanya ditentukan dari kemampuan berpikir logis, masih banyak kemungkinan faktor-faktor lain yang juga dapat mempengaruhi prestasi belajar siswa. Faktor eksternal misalnya model pembelajaran yang diterapkan juga tidak sepenuhnya dapat mempengaruhi prestasi belajar siswa. Setiap siswa memiliki kecenderungan pengaruh prestasi belajar yang berbedabeda.

Salah satu faktor yang mungkin menyebabkan hal tersebut adalah adanya faktor internal yang berupa intelegensi yang dapat mempengaruhi prestasi belajar seseorang. Intelegensi terdiri dari tujuh kecakapan primer yaitu kemampuan menggunakan bahasa (verbal comprehension), kefasihan kata-kata (word fluency), kecakapan menghitung (number), kemampuan orientasi ruang (space), kemampuan memori (memory), kemampuan mengamati dengan cermat dan tepat (perceptual speed), serta kemampuan berpikir logis (reasoning) [13].

Berdasarkan hasil uji Kruskal Wallis pada prestasi belajar aspek sikap disimpulkan bahwa ada interaksi antara model pembelajaran Discovery Learning dan Problem Based Learning dengan kemampuan berpikir logis pada materi pokok Kelarutan dan Hasil Kali Kelarutan (Ksp). Apabila dianalisis berdasarkan Tabel 5, diketahui rata-rata prestasi belajar aspek sikap tertinggi adalah pada siswa yang memiliki kemampuan berpikir logis rendah pada kelas eksperimen I (dengan model pembelajaran Discovery Learning). Berdasarkan perumusan hipotesis dimungkinkan pada model pembelajaran baik Discovery Learning maupun model pembelajaran Problem Based Learning akan lebih didukung oleh siswa yang memiliki kemampuan berpikir logis tinggi. Seperti pada pembahasan sebelumnya bahwa aspek sikap pada penelitian ini disesuaikan dengan kurikulum 2013 yang mana pembegian 
aspek sikap menjadi sikap spiritual dan sikap sosial (jujur, percaya diri, tanggung jawab, dan kerja sama). Disisi lain, model pembelajaran merupakan salah satu faktor eksternal yang hanya bersifat memfasilitasi kegiatan belajar mengajar sehingga tidak bisa merubah sikap siswa dalam waktu singkat karena sikap dipengaruhi oleh banyak faktor lain. Kemampuan berpikir logis adalah kemampuan dari seseorang untuk menangkap dan mengasosiasiakan data \& informasi yang ada serta untuk merubah sikap tersebut tidak dapat ditentukan oleh satu faktor internal saja [14].

Berdasarkan hasil uji Kruskal Wallis pada prestasi belajar aspek ketrampilan disimpulkan bahwa tidak ada interaksi antara model pembelajaran Discovery Learning dan Problem Based Learning dengan kemampuan berpikir logis pada materi pokok Kelarutan dan Hasil Kali Kelarutan (Ksp). Hasil analisis data ratarata di atas diketahui bahwa siswa yang memiliki kemampuan berpikir logis tinggi pada model pembelajaran Problem Based Learning memiliki rata-rata nilai aspek ketrampilan yang besar. Dan apabila kita andingkan dengan rata-rata pada kondisi siswa yang lain menunjukkan adanya perbedaan-perbedaan yang cukup signifikan. Akan tetapi berdasarkan hasil statistik uji menun-jukkan tidak ada interaksi, hal ini dimungkinkan karena data yang diambil pada prestasi belajar aspek ketrampilan kurang mencukupi dan kurang menjelaskan ketrampilan mereka. Untuk menentukan penilaian pada aspek ketrampilan, dapat dilakukan dengan cara penilaian keterampilan yang berbeda antara dua kategori kemam-puan berpikir logis antara dua kelas eksperimen [15].

\section{KESIMPULAN}

Berdasarkan hasil penelitian dan analisis data dapat disimpulkan bahwa: (1) Penerapan model pembelajaran Discovery Learning dengan model pembelajaran Problem Based Learning (PBL) tidak menunjukkan perbedaan prestasi belajar siswa pada materi pokok Kelarutan dan Hasil Kali Kelarutan (Ksp) baik dari aspek pengetahuan, aspek sikap, maupun, aspek ketrampilan. (2) Kemampuan berpikir logis siswa berpengaruh pada prestasi belajar aspek pengetahuan dan tidak berpengaruh pada prestasi belajar aspek sikap dan aspek ketrampilan pada materi pokok Kelarutan dan Hasil Kali Kelarutan (Ksp). (3) Pada prestasi belajar siswa pada aspek sikap menunjukkan adanya interaksi antara model pembelajaran Discovery Learning dan model pembelajaran Problem Based Learning (PBL) dengan kemampuan berpikir logis siswa. Akan tetapi pada aspek pengetahuan dan aspek ketrampilan tidak menunjukkan adanya interaksi antara model pembelajaran Discovery Learning dan model pembelajaran Problem Based Learning (PBL) dengan kemampuan berpikir logis siswa.

\section{DAFTAR PUSTAKA}

[1] Kementerian Pendidikan dan Kebudayaan, Rekap Hasil Ujian Nasional (UN), diakses dari puspendik.pendigbud.go.id pada 7 November 2018 14:20.

[2] Sugiyanto, 2009, Model-model Pembelajaran Inovatif, Yuma Pustaka, Surakarta.

[3] S. R. Putra, 2013, Desain Belajar Mengajar Kreatif Berbasis Sains, Diva press, Yogyakarta.

[4] A. Salmon, dkk, 2012, Belajar dan Pembelajaran Matematika Model Pembelajaran DL, Ambon.

[5] D. G. B. Krisna, A. Adiarta, dan N. Santiyandnya, 2015, e-Journal JPTE Universitas Pendididkan Ganesha, 4(1), 22-33.

[6] S. Hadi, 2005, Logika (Filsafat Berpikir), UNS Press, Surakarta.

[7] A. Sudrajat, 2008, Jurnal Pendidikan Karakter, 1(1), 47-58.

[8] D. R. Kusumastuti, 2013, Jurnal IImiah Pendidikan Ekonomi, 2(4), 365-370. 
[9] Tobin \& Capie (1981), Educational and Psychological Measurement, $41,413-423$.

[10] A. Rakhmawan, dan M. Vitasari, 2016, Jurnal Pendidikan dan Pembelajaran IPA, 2(1), 99-109.

[11] L. Wiji, W. Supandi, dan M. A. Martoprawiro, 2014, Cakrawala Pendidikan, (1), 147-156.

[12] M. R. Umami, S. Budi, 2016, Jurnal Pendidikan Kimia (JPK), 5(3), 9-17.
[13] L. N. Widhiastuti, S. Mulyani, dan Haryono, 2017, Jurnal Penelitian Pendidikan, 20(2), 104-119.

[14] L. Y. Fah, 2009, Journal of Science and Mathematics, 32(2), 161-187.

[15] A. D. Candra, S. Mulyani, and Ashadi, 2016, Jurnal Penelitian Pendidikan,19(2), 170-181. 